\title{
Click Beetles, Alaus spp. (Insecta: Coleoptera: Elateridae) ${ }^{1}$
}

R. E. Woodruff ${ }^{2}$

\section{Introduction}

Because of their striking appearance and their large size, beetles of the genus Alaus are commonly brought to the attention of nursery inspectors and Cooperative Extension Service agents. Two species in this genus, A. myops (Fabr.) and A. oculatus (Linn.), are found in Florida.

\section{Distribution}

A. oculatus is widespread in the eastern United States, being recorded by Leng (1920: 167) from "Indiana, Atlanta States -- Texas, Florida." Blatchley (1910: 717) listed it from throughout Indiana; Fattig (1951: 5) listed 19 localities scattered over Georgia; and Dietrich (1945: 9) listed it as being found throughout the state of New York. The Florida State Collection of Arthropods (FSCA) contains records from the following Florida counties: Alachua, Columbia, Dade, Duval, Gulf, Hardee, Hillsborough, Orange, Palm Beach,Seminole, and St. Lucie. A. myops is more common in the southeastern United States although it is occasionally found in the northern states; recorded by Leng (1920: 167) reported from "Indiana, Middle and Southern States, Florida." Blatchley (1910: 719) listed one record for Indiana and stated "rare north of the Ohio River". Fattig (1951: 5) listed 20 localities scattered over Georgia. Dietrich(1945: 10) listed nine localities in New York. The FSCA contains records from the following Florida counties: Alachua, Baker, Brevard, Dade, Hardee, Highlands, Liberty, Monroe, Orange, Polk, and Seminole.

\section{Description}

\section{Adults}

The adults reach a length of 24 to $45 \mathrm{~mm}$. The photographs below illustrate why these beetles are so striking. The large "false eyes" on the pronotum of adults are characteristic of this genus. Presumably these spots have some selective value in frightening a would-be predator. The true eyes are much smaller and are located on the head anterior to the "false eyes." Both Florida species have a mottled pattern on the dorsal surface created by minute scales. These patterns are variable but similar to those shown in the photographs and are effective in concealment.

1. This document is EENY-085 (originally published as DPI Entomology Circular No. 109), one of a series of Featured Creatures from the Entomology and Nematology Department, Florida Cooperative Extension Service, Institute of Food and Agricultural Sciences, University of Florida. Published: June 1999. This document is also available on Featured Creatures Website at http://creatures.ifas.ufl.edu. Please visit the EDIS Website at http://edis.ifas.ufl.edu. Additional information on these organisms, including many color photographs, is available at the Entomology and Nematology Department WWW site at http://entnemdept.ifas.ufl.edu/.

2. R. E. Woodruff, Florida Department of Agriculture and Consumer Services, Division of Plant Industry, Gainesville, FL.

The Institute of Food and Agricultural Sciences (IFAS) is an Equal Employment Opportunity - Affirmative Action Employer authorized to provide research, educational information and other services only to individuals and institutions that function without regard to race, creed, color, religion, age, disability, sex, sexual orientation, marital status, national origin, political opinions or affiliations. For information on obtaining other extension publications, contact your county Cooperative Extension Service office. Florida Cooperative Extension Service / Institute of Food and Agricultural Sciences / University of Florida / Larry R. Arrington, Interim Dean 


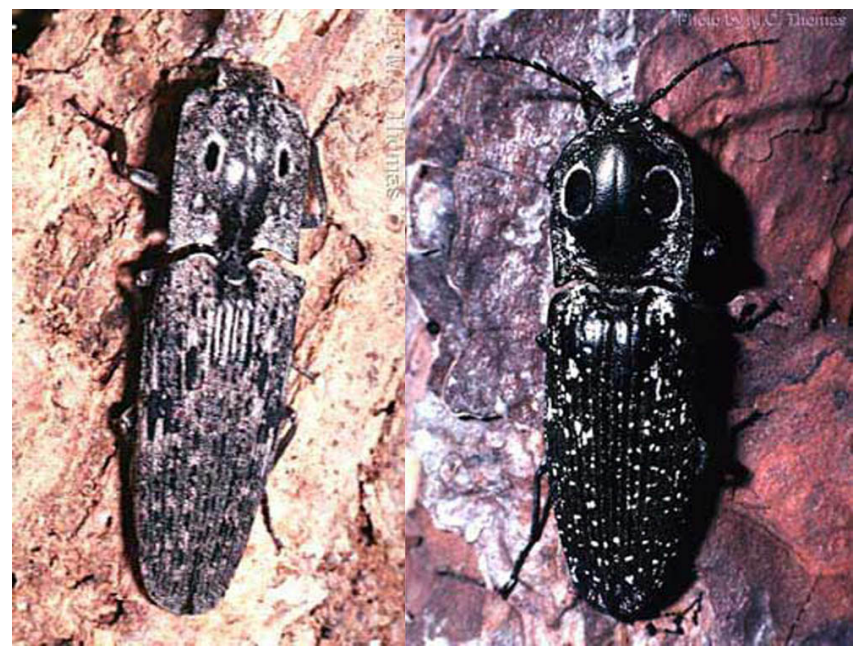

Figure 1. Adults of the click beetles Alaus myops (Fabr.), left, and Alaus oculatus (Linn.), right. Credits: M.C.

Thomas, Division of Plant Industry

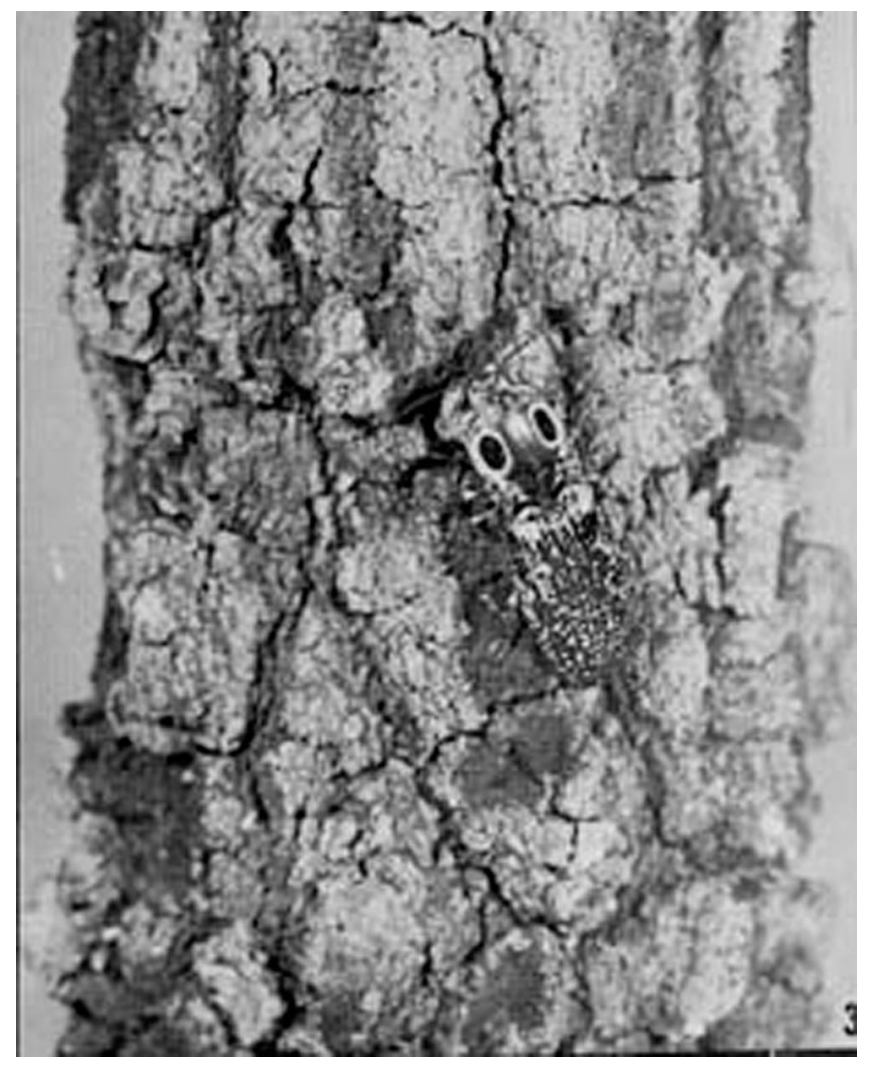

Figure 2. The adult click beetle Alaus oculatus (Linn.) on oak bark. Credits: E.M. Collins, Jr, Division of Plant Industry

\section{Larvae}

The larvae are large (up to 2 inches), heavily sclerotized, smooth, stout, and yellowish to dark brown. That of $A$. oculatus is described technically by Jewett (1946: 16, Fig. 53-55) and Peterson (1951: 176, Fig. C46, K, L, M). The head is nearly black and the last four abdominal segments are dark brown. The last dorsal abdominal segment (9th) is armed with many conical tubercles and terminates in a pair of forked teeth (urogamphi). The 10th segment has two anal hooks and 10 to 12 spines and setae anterior to the anus. The spiracles are biforous, located on the ventral side of the mesothorax and on the dorso-lateral part of the first through eighth abdominal segments. I have not found a description or illustration of the larva of $A$. myops.

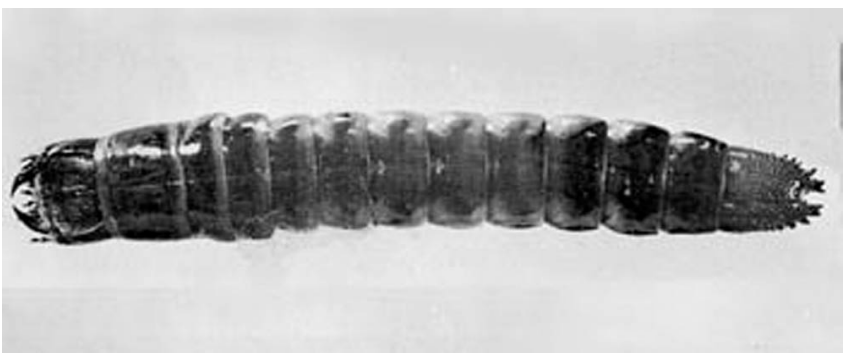

Figure 3. Mature larva of the click beetle Alaus oculatus (Linn.). Credits: E.M. Collins, Division of Plant Industry

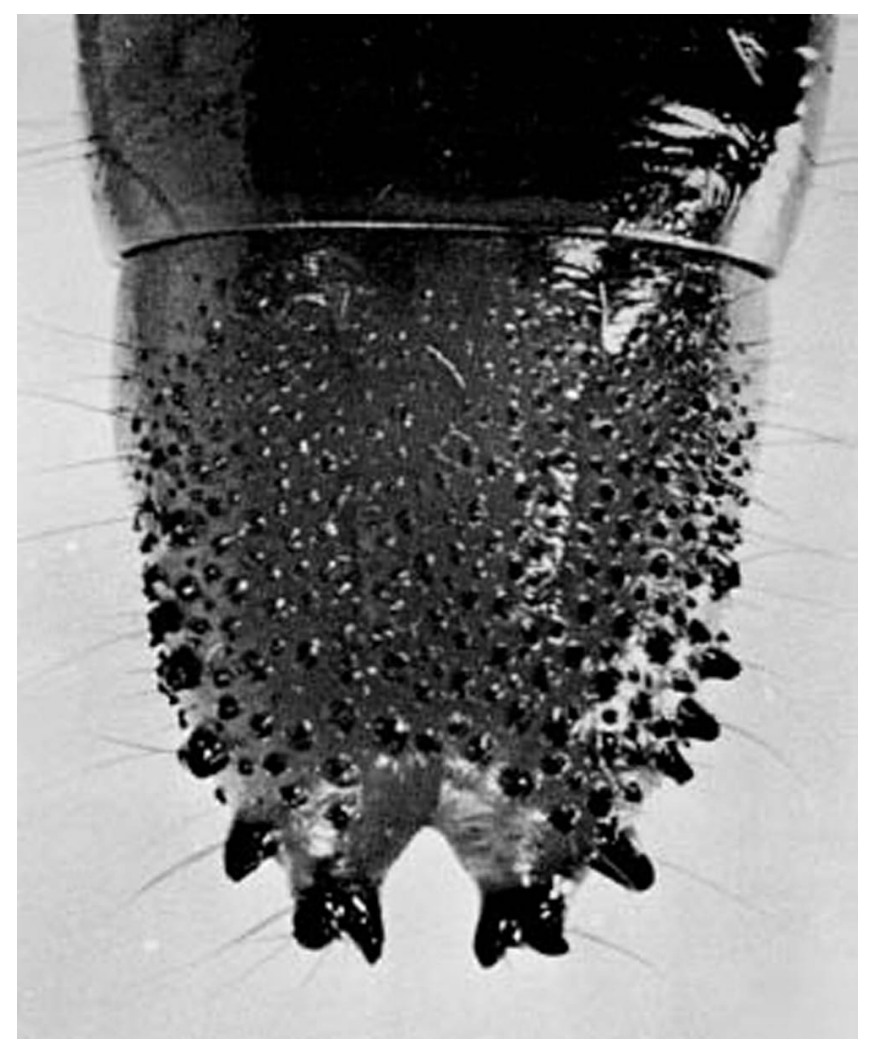

Figure 4. Dorsal view of the last (9th) abdominal segment of the mature larva of the click beetle Alaus oculatus (Linn.). Credits: E.M. Collins, Division of Plant Industry 


\section{Biology}

The ferocious looking larva and the large beetle might be expected to be a serious pest. However, the adults probably feed little and the larvae are effective predators on many wood-boring beetle larvae. Craighead (1950: 185) stated that larvae of oculatus were voracious on wood borers, and that during their development caged specimens each devoured more than 200 cerambycid larvae. They are most often encountered in rotting stumps of oak, cherry, and apple, whereas myops is usually found in pine stumps and logs. Rohwer (1920: 443) listed Xorides catomus Davis (Ichneumonidae) as a parasite of the larvae.

\section{Key to Florida Species of Alaus}

1. "Eye spots" less than one-fourth the length of pronotum; base color or dorsum brownish, the scales mostly grey and covering more than half the surface; associated with pines. .... myops (Fabr.)

1'. "Eye spots" about one-third the length of the pronotum; base color or dorsum black, the scales mostly white and covering less than half the surface; associated with hardwoods..... oculatus (Linn.)

\section{Selected References}

Blatchley, W.S. 1910. Coleoptera or Beetles Known to Occur in Indiana. Nature Publishing Company, Indianapolis, IN 1385 p.

Craighead, F.C. 1950. Insect Enemies of Eastern Forests. USDA Miscellaneous Publication 657: 1679.

Dietrich, Henry. 1945. The Elateridae of New York State. Cornell University Agricultural Experiment Station Memorandum 269: 1-79.

Fattig, P.W. 1951. The Elateridae or click beetles of Georgia. Emory University Museum Bulletin 10: 1-25.

Jewett, H.H. 1946. Identification of some larval Elateridae found in Kentucky. Kentucky Agricultural Experiment Station Bulletin 489: 1-40.

Knull, J.N. 1932. Notes on Coleoptera. - No. 3. Entomological News 43: 42-45.
Leng, C.W. 1920. Catalogue of the Coleoptera of America, North of Mexico. John D. Sherman, Jr., Mount Vernon, N.Y. 470 p.

Pechuman, L.L. 1937. An annotated list of insects found in the bark and wood of Ulmus americana L. in New York State. Bulletin of Brooklyn Entomological Society 32: 8-21.

Peterson, Alvah. 1951. Larvae of Insects; Part II -- Coleoptera, Diptera, Siphonaptera, Mecoptera, Trichoptera. Edwards Bros., Inc., Ann Arbor, Mich. $416 \mathrm{p}$.

Rohwer, S.A. 1920. The North American ichneumon-flies of the tribes Labenini, Rhyssini, Xoridini, Odontomerini, and Phytodietini. Proceedings of the U.S. National Museum 57: 405-474. 